\title{
Biosorptive behaviour of mango leaf powder and rice husk for arsenic(III) from aqueous solutions
}

\author{
S. Kamsonlian · S. Suresh • V. Ramanaiah • \\ C. B. Majumder $\cdot$ S. Chand $\cdot$ A. Kumar
}

Received: 26 January 2011/Revised: 28 August 2011/Accepted: 17 November 2011/Published online: 12 April 2012

(c) CEERS, IAU 2012

\begin{abstract}
The present study deals with the biosorption of As(III) from aqueous solution using mango leaves powder (MLP) and rice husk (RH) in a batch operation. Scanning electron microscopy and Fourier transformation infrared spectrometry analysis shows the surface texture of biosorbents and metal binding of functional groups of before and after biosorption of As(III). The optimum $\mathrm{pH}$ was obtained at 7 and 6 with 7 and $6 \mathrm{~g} / \mathrm{l}$ of dosage of MLP and $\mathrm{RH}$, respectively. The adsorption of As(III) onto MLP and RH was favourably influenced by an increase in temperature. Equilibrium data were well represented by the Freundlich isotherm model. Nitric acid and ethylenediaminetetra acetic acid was found to be a better eluant for the desorption followed by hydrochloric acid and sodium hydroxide of As(III) with a maximum desorption efficiency of $69.5,48.5$ and $79.4,86.3 \%$, respectively. The pseudosecond-order kinetic model was found to best fitted of the experimental data over the equilibrium time at $32 \mathrm{~h}$. The positive values of heat of adsorption $(23.89 \mathrm{~kJ} / \mathrm{mol}$ for MLP and $52.26 \mathrm{~kJ} / \mathrm{mol}$ for $\mathrm{RH}$ ) indicate the endothermic nature of the adsorption process. The thermodynamic study
\end{abstract}

S. Kamsonlian · C. B. Majumder · S. Chand

Department of Chemical Engineering,

Indian Institute of Technology Roorkee,

Roorkee 247667, India

\section{S. Suresh $(\bowtie)$}

Department of Chemical Engineering,

Maulana Azad National Institute of Technology,

Bhopal 462051, India

e-mail: sureshpecchem@gmail.com

V. Ramanaiah · A. Kumar

Department of Civil Engineering,

Indian Institute of Technology Roorkee,

Roorkee 247667, India showed the spontaneous nature of the sorption of As(III) onto MLP and RH.

Keywords Arsenic - Adsorption - Biomass - Kinetic . Isotherm · Desorption

\section{Introduction}

Industrial revolution thrusts heavy metals contamination into the environment, which threatens human lives and the aquatic system (Chen et al. 2007; Khan et al. 2008). Various industries produce and discharge wastes containing different heavy metals into the environment, such as mining and chemicals processing units, surface finishing industry, energy and fuel production, fertilizer and pesticide industry and application, metallurgy, iron and steel, electroplating, electrolysis, electro-osmosis, leather working, photography, electric appliance manufacturing, metal surface treating, aerospace and atomic energy installation (An et al. 2001; Sha et al. 2010; Wang et al. 2009; Wei et al. 2009). Arsenic contamination is one of the most challenging environmental problems (Amin et al. 2006). Millions of people worldwide are exposed to high concentration of arsenic from groundwater, which the source of drinking water. Arsenic is widely distributed in nature and released into the environment through natural sources, industrial processes and agriculture usage (Singh et al. 2010; Chio et al. 2009; Chatterjee et al. 1995; Mandal et al. 1996; Duker et al. 2005; Tapio and Grosche 2006). Continued ingestion of arsenic for a long period leads to chronic arsenic poisoning; acute poisoning typically include vomiting, oesophageal and abdominal pain, diarrhoea, skin lesions, cancer of the skin, lungs, urinary bladder, and kidney, as well as other skin changes such as 
pigmentation changes and thickening (hyperkeratosis), black foot disease (Rahman et al. 2005; Atkins et al. 2007; Yoshida et al. 2004; Chaudhuri et al. 2008; Pandey et al. 2002; Jack et al. 2003; Duker et al. 2005; Tseng et al. 2005). Because of high impact on human health even at low concentrations several regulating agencies set their maximum contamination level of arsenic in drinking water values e.g., World Health Organization as $0.01 \mathrm{mg} / \mathrm{l}$, French as $0.015 \mathrm{mg} / \mathrm{l}$, United State Environmental Protection Agency as $0.01 \mathrm{mg} / \mathrm{l}$, Vietnam and Mexico as $0.05 \mathrm{mg} / \mathrm{l}$, European Union as $0.01 \mathrm{mg} / \mathrm{l}$, Australia as $0.007 \mathrm{mg} / \mathrm{l}$, Germany as $0.01 \mathrm{mg} / \mathrm{l}$, Bangladesh and India as $0.05 \mathrm{mg} / \mathrm{l}$ (Anawar et al. 2003; Choong et al. 2007; Maji et al. 2008; Zhu et al. 2009; Barakat and Sahiner 2008; Mohapatra et al. 2008). Various methods are available in the literature such as ion-exchange, solvent extraction, chemical precipitation, membrane processes, electrocoagulation and adsorption (Mohan and Pittman 2007; Lataye et al. 2009; Suresh et al. 2010). The interest in the development of cost-effective methods for the removal and recovery of heavy metals from contaminated waters has greatly increased and using different biomaterials as adsorbents. Among the various resources in biological wastes, both dead and live biomass, exhibit particularly interesting metal-binding capacities (Volesky 1994; Costa et al. 1996; Feng et al. 2011). In recent years, agricultural by products have been widely studied for metal removal from water. These include peat, wood, pine bark, banana pith, soybean, cottonseed hulls, peanut, shells, hazelnut shell, rice husk (RH), sawdust, wool, orange peel, compost and leaves (Khalid et al. 1999; Wan Ngah et al. 2007; Feng et al. 2011). As a low cost, mango leaves powder (MLP) and rick husk is an attractive and inexpensive option for the biosorption removal of dissolved metals.

The aim of this study was to evaluate effectiveness of biomass prepared from MLP and RH to remove As(III) from aqueous solution. The influence of various parameters like effect of $\mathrm{pH}$, contact time, sorbents dosage and temperature has been studied. Kinetic and thermodynamic studies are also evaluated in this present study.

\section{Materials and methods}

\section{Chemicals and reagents}

All chemicals used were of AR grade and Milli-Q water was used for stock solution and all the experiments. A stock solution of $\mathrm{As}(\mathrm{III})(1,000 \mathrm{mg} / \mathrm{l})$ was prepared by dissolving appropriate quantities of sodium meta arsenite $\left(\mathrm{As}_{2} \mathrm{O}_{3}\right.$ ) (Himedia Chemicals, New Delhi, India). Potassium iodides, sodium hydroxide $(\mathrm{NaOH})$, nitric acid $\left(\mathrm{HNO}_{3}\right)$, ethylenediaminetetra acetic acid (EDTA), sodium carbonate $\left(\mathrm{Na}_{2} \mathrm{CO}_{3}\right)$ were purposed from S.D. Fine Chemicals, Mumbai, India. Silver diethyldithiocarbamate (SDDC) reagent was prepared by dissolving $1 \mathrm{~g}$ of SDDC in $200 \mathrm{ml}$ of pyridine (Ranbaxy Fine Chemicals, New Delhi, India).

Preparation and characterisation of biosorbents

Rice husk and mango leaves were purchased/collected from the local market/institute campus of India Institute of Technology Roorkee, India. The leaves ware cleaned with deionized water to remove soluble lighter materials and air dried at room temperature, and then kept inside hot air oven at temperature of $80^{\circ} \mathrm{C}$, for overnight. The biomass was grinded in ball mill and sieved up to $<425 \mu \mathrm{m}$. Morphology of MLP and RH surface was determined susing scanning electron microscopy (SEM). Percentage of volatile matter, moisture content, ash and fixed carbon were determined through proximate analysis. Functional groups present on the surface of MLP and RH was analysed by Fourier transform infrared spectroscopy (FTIR) analysis, using a Nicolet FTIR, model 6700. The spectrum was obtained with resolution range of $400-4,000 \mathrm{~cm}^{-1}$ with number of cumulative scans.

Batch sorption studies

For each of the batch experiments, a known concentration of $100 \mathrm{ml}$ of As(III) was taken in a 250-ml stoppered conical flask with a known amount of MLP or RH (g/l) and the initial $\mathrm{pH}$ of the solutions were adjusted using $\mathrm{H}_{2} \mathrm{SO}_{4}$ and $\mathrm{NaOH}$ solutions. The mixture was agitated in a temperature controlled orbital shaker with a constant speed of $150 \mathrm{rpm}$ at $303 \mathrm{~K}$. The samples were withdrawn and centrifuged using a research centrifuge (Remi Instruments, Mumbai, India) at $10,000 \mathrm{rpm}$ for $5 \mathrm{~min}$. In all the experiments, the solution $\mathrm{pH}$ was maintained constant using buffer system of potassium dihydrogen orthophosphate $\left(\mathrm{KH}_{2} \mathrm{PO}_{4}\right)$ and sodium hydroxide $(\mathrm{NaOH})$. The supernatant solutions after centrifuged were analysed using spectrophotometer which gives the residual concentration of As(III).

The As(III) removal from the solution was calculated as

$\%$ As(III) removal $=100\left(C_{0}-C_{\mathrm{t}}\right) / C_{0}$

and the adsorptive uptake of As(III) by MLP or RH (g/l) $(\mathrm{mg} / \mathrm{g})$, was calculated as

$q_{\mathrm{t}}=\left(C_{0}-C_{\mathrm{t}}\right) V / w$

where, $C_{0}$ is the initial As(III) concentration $(\mathrm{mg} / \mathrm{l}), C_{\mathrm{t}}$ is the As(III) concentration $(\mathrm{mg} / \mathrm{l})$ at any time $t ; V$ is the volume of the solution (l) and $w$ is the mass of the adsorbent $(\mathrm{g})$. 
Arsenic and data analysis

Arsenic(III) concentration was measured by silver diethyldithiocarbamate (SDDC) spectrophotometer method (Zavar et al. 2000; Kamsonlian et al. 2011). Arsine reacts with this reagent formed red coloured silver solution having maximum absorbance at wavelength $540 \mathrm{~nm}$ (IS 3025:1988 and ASTM D 2972:2008). Arsenic(III) removal were analysed using various models by non-linear regression using the MS-EXCEL 2007 solver.

Sorption isotherms and modelling

The successful representation of the dynamic sorption separation of solute from solution onto biosorbent depends upon a good description of equilibrium separation between two phases. Different isotherms have been used to describe sorption equilibrium for the uptake of As(III) species on the solid surface of MLP and RH. Langmuir and Freundlich isotherms were being used for the present experimental work. The study of isotherm was carried out by varying initial concentration of $\mathrm{As}$ (III) $20-1,000 \mathrm{mg} / \mathrm{l}$ at various temperatures from $10-45{ }^{\circ} \mathrm{C}$. Large number of researchers used Freundlich (1906), Langmuir (1918), Temkin and Pyzhev (1940) and Redlich and Peterson (1959) isotherm equations to represent equilibrium sorption data using sorbent-metal ion contaminants systems. The hybrid fractional error function (HYBRID) (Porter et al. 1999) was used as a criterion in finding the best isotherm model to fit the experimental data. The HYBRID is given by following equation:

HYBRID $=\frac{100}{n-p} \sum_{i=1}^{n}\left[\frac{\left(q_{\mathrm{e}, \exp }-q_{\mathrm{e}, \text { calc }}\right)}{q_{\mathrm{e}, \exp }}\right]_{i}$

where, $q_{\mathrm{e}, \text { exp }}$ and $q_{\mathrm{e}, \mathrm{cal}}$ are the experimental and calculated equilibrium adsorbate uptake, respectively; and $n$ is the number of data points.

Classical thermodynamics of the adsorption process gives the following relationship between $\Delta G_{0}, \Delta H_{0}, \Delta S_{0}$ and equilibrium adsorption constant $\left(K_{\mathrm{D}}\right)$ (Suresh et al. 2010)

$\ln K_{\mathrm{D}}=\frac{-\Delta G_{0}}{R T}=\frac{\Delta S_{0}}{R T}-\frac{\Delta H_{0}}{R} \frac{1}{T}$.

where, $T$ is the absolute temperature $(\mathrm{K}), R$ the universal gas constant $\left(8.314 \times 10^{-3} \mathrm{~kJ} / \mathrm{mol} \mathrm{K}\right)$ and $K_{\mathrm{D}}=\left(q_{\mathrm{e}} / C_{\mathrm{e}}\right)$ the single point or linear sorption distribution coefficient. Thus, $\Delta H_{0}$, which is the enthalpy change $(\mathrm{kJ} / \mathrm{mol})$, can be determined from the slope of the linear Van't Hoff plot, i.e., $\ln K_{\mathrm{D}}$ versus $(1 / T)$. This $\Delta H_{0}$ corresponds to the isosteric heat of adsorption $\left(\Delta H_{\text {st }, 0}\right)$ with zero surface coverage (i.e., $q_{\mathrm{e}}=0$ ) (Suzuki and Fujii 1982). $K_{\mathrm{D}}$ at $q_{\mathrm{e}}=0$ can be obtained from the intercept of the $\ln q_{\mathrm{e}} / C_{\mathrm{e}}$ versus $q_{\mathrm{e}}$ plot (Srivastava et al. 2007; Suresh et al. 2010).

\section{Sorption kinetics}

The distribution equilibrium between metal bound to the biomass and metal concentration in the surrounding fluid phase. Pseudo-first-order and Pseudo-second-order model were used to experimental data for determination of rate constants (Langmuir 1918; Ho and McKay 1999).

\section{Desorption}

The batch desorption was studied using solvent elution method. In the solvent elution study, the MLP and RH utilised for the sorption was separated from the solution. The As(III)-loaded MLP and RH (0.2 g) was then agitated at $150 \mathrm{rpm}$ in a series of $250 \mathrm{ml}$ conical flasks containing $50 \mathrm{ml}$ of aqueous solution $(0.1 \mathrm{~N})$ of $\mathrm{HCl}, \mathrm{HNO}_{3}, \mathrm{H}_{2} \mathrm{SO}_{4}$, ETDA, $\mathrm{NaOH}, \mathrm{Na}_{2} \mathrm{CO}_{3}$, distilled water, acetone and of known concentrations at $303 \mathrm{~K}$ for $32 \mathrm{~h}$ in an orbital shaker (Sekhar et al. 2004; Suresh et al. 2010).

\section{Results and discussion}

Biosorption of As(III) ions onto the surface of a biological material is affected by several factors, such as biomass concentration, initial $\mathrm{pH}$, initial As(III) ion concentration, time and temperature.

\section{Characterisation of biosorbents}

Physical characterisation of the biosorbents was carried out by SEM and the respective micrographs are presented in Fig. 1. It is clearly seen that the evident morphological difference between the surface of the MLP and RH. The proximate analyses of the MLP and RH was carried by standard procedure (IS 1350 part I 1984; IS 355:1984 1985) and showed the presence of percentage weight basis: moisture content 5.8, 2.2; volatile matter $81.49,61.3$; ash content 9.58, 7.03; fixed carbon 3.13, 1.13, respectively.

For preliminary qualitative analysis of the main functional groups that might be involved in As(III) before and after biosorption by FTIR spectroscopic analysis was done in solid phase in the range of $500-4,000 \mathrm{~cm}^{-1}$. Figure $2 \mathrm{a}$ shows that FTIR analysis of MLP biomass. Characteristic peak occurs around $1,500 \mathrm{~cm}^{-1}$ indicating presence of $\mathrm{C}-$ $\mathrm{C} / \mathrm{N}-\mathrm{C}$ stretching (Kara et al. 2004). There are three characteristic bands at around 1,780, 1,380 and $830 \mathrm{~cm}^{-1}$. The $1,380 \mathrm{~cm}^{-1}$ band is the strongest and is relatively broad while the other two absorptions are weaker and very narrow; this indicates the presence of nitrate compounds. 

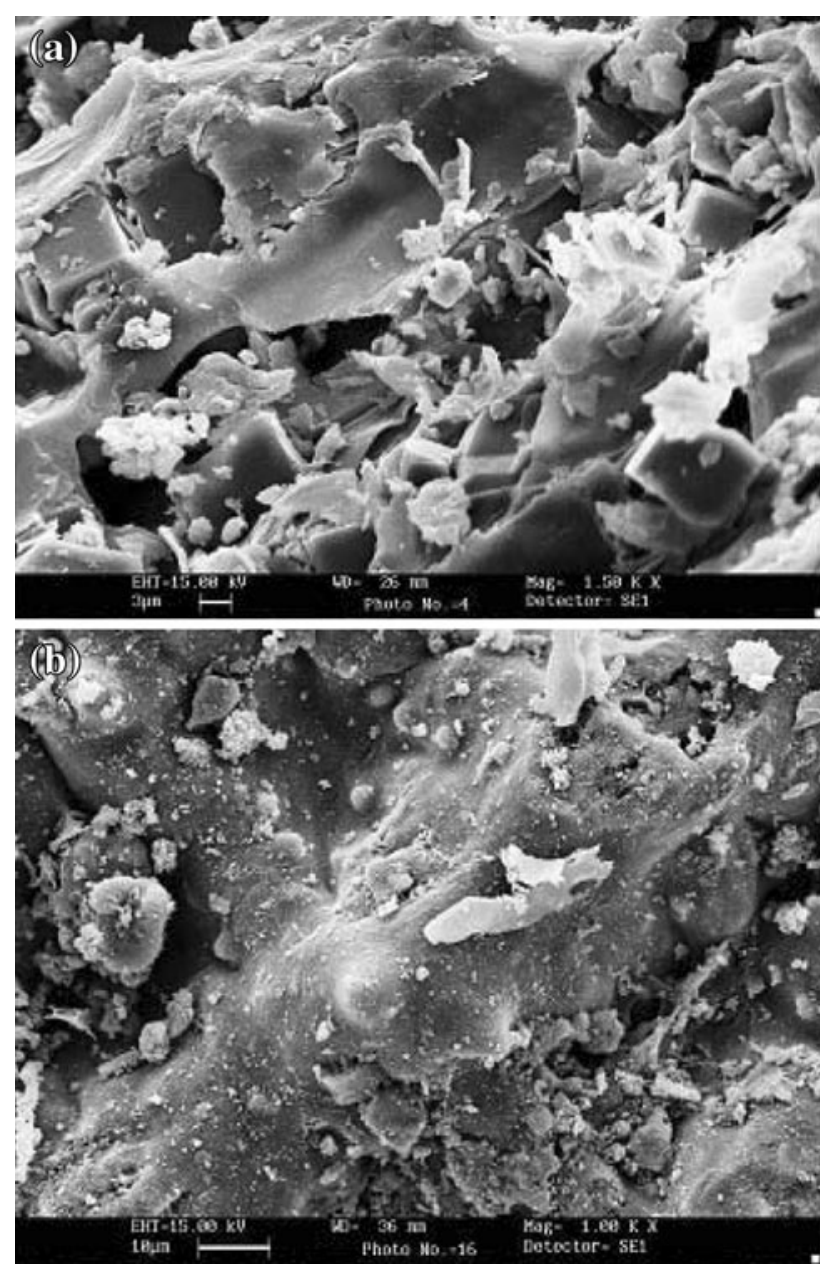

Fig. 1 SEM micrograph of biosorbents. a Mango leaf powder, and b rick husk

The broad peak between 3,200 and $3,600 \mathrm{~cm}^{-1}$ is indicative of the existence of hydroxyl groups of macromolecular association (cellulose, pectin, etc.) (Arslanoglu et al. 2008). The low-frequency bands around $1,550 \mathrm{~cm}^{-1}$ indicating the presence of amino groups. The surface complex formation between dissolved metal ion species and surface functional groups with biosorption capacity is a function of its density as well as the nature of metal ions in solution (Urik et al. 2009). Figure 2b shows the FTIR analysis for As(III)-loaded MLP biomass. Aliphatic groups were found in many compounds that the infrared spectroscopy was likely to encounter. The most important vibration modes were the $\mathrm{C}-\mathrm{H}$ stretching around $3,000 \mathrm{~cm}^{-1}$ and the $-\mathrm{CH}$ deformation modes around $1,460 \mathrm{~cm}^{-1}$ and $1,380 \mathrm{~cm}^{-1}$. The atoms directly attached to the aliphatic groups may result in significant shifts from the standard frequencies. In particular adjacent atoms with high electro negativity will shift the band locations to higher frequencies. The $\mathrm{CH}_{3}$ asymmetric stretching vibration occurred at $2,975-2,950 \mathrm{~cm}^{-1}$ while the $\mathrm{CH}_{2}$ absorption occurred at about $2,930 \mathrm{~cm}^{-1}$. The symmetric $\mathrm{CH}_{3}$ vibration occurs at $2,885-2,865 \mathrm{~cm}^{-1}$ while the $\mathrm{CH}_{2}$ absorption occurs at about $2,870-2,840 \mathrm{~cm}^{-1}$. The peak at the wavelength of 885 and $820 \mathrm{~cm}^{-1}$ are negligible. This represents presence of As(III) in the biomass (Mondal et al. 2006).

Figure 3a shows the FTIR spectra of RH biomass and there were four or more $\mathrm{CH}_{2}$ in a row and a rocking absorption was found around wave number of $720 \mathrm{~cm}^{-1}$. This absorption splits into two bands when the number of adjacent methylene groups. The presence of the $t$-butyl group can be confirmed by the presence of bands around 1,255 and $1,210 \mathrm{~cm}^{-1}$ while the isopropyl group shows bands near 1,170 and $1,145 \mathrm{~cm}^{-1}$. The $\mathrm{CH}_{3}$ asymmetric deformation vibration occurs at $1,470-1,440 \mathrm{~cm}^{-1}$. The table stated below represents the functional groups presented on the surface of $\mathrm{RH}$ at different wavelengths $\left(\mathrm{cm}^{-1}\right)$. The large band near $3,400 \mathrm{~cm}^{-1}$ was the stretching vibration of $-\mathrm{OH}$ groups (Liu et al. 2010). Figure $3 \mathrm{~b}$ shows the FTIR spectra of As(III)-loaded RH biomass. Carboxylic acid salts typically show a strong, characteristic asymmetric stretching absorption from the $\mathrm{CO}_{2}$-group in the $1,650-1,550 \mathrm{~cm}^{-1}$ region. The corresponding symmetric stretching absorption occurs at around $1,440-1,335 \mathrm{~cm}^{-1}$. Fairly strong rocking in and out of plane deformation absorptions are observed in the $770-400 \mathrm{~cm}^{-1}$ region. The peak at $1,468 \mathrm{~cm}^{-1}$ can be attributed to the methylene $\mathrm{C}-\mathrm{H}$ bend (Baraka et al. 2007). Asymmetric and symmetric stretching vibrations of ionic carboxylic groups $\left(-\mathrm{COO}^{-}\right)$, respectively, appeared at 1,624 . The peaks at $1,373 \mathrm{~cm}^{-1}$ may be assigned to symmetric stretching of $-\mathrm{COO}^{-}$of pectin and aliphatic acid group vibration around $1,228 \mathrm{~cm}^{-1}$ to deformation vibration of $\mathrm{C}-\mathrm{O}$ and stretching formation of $-\mathrm{OH}$ of carboxylic acids and phenols (Iqbal et al. 2009).

\section{Effect of $\mathrm{pH}$}

Many researchers have shown that $\mathrm{pH}$ is an important factor for metal sorption by biological materials (Saeed et al. 2009). It was well known that the $\mathrm{pH}$ can strongly influence the solution chemistry of the sorbates, the activity of functional groups on the biomass cell walls, as well as the competition of sorbates for the binding sites (Liu et al. 2010). The effect of $\mathrm{pH}$ on the biosorption of As(III) onto MLP and RH was shown in Fig. 4. pH was the strong influence parameter for the removal of As(III) ions from aqueous solution. The $\mathrm{pH}<2.0$ or lower, the percentage As(III) removal was lower compared to $\mathrm{pH}$ $>2$. The lower biosorption at low $\mathrm{pH} 2.0$ may be due to the fact that high concentration and high mobility of $\mathrm{H}^{+}$ ions, the $\mathrm{H}^{+}$ions are preferentially adsorbed rather than the metal ions (Feng et al. 2011). At $\mathrm{pH}>2.0$, a sharp increase in the percentage of As(III) sorption due to the 

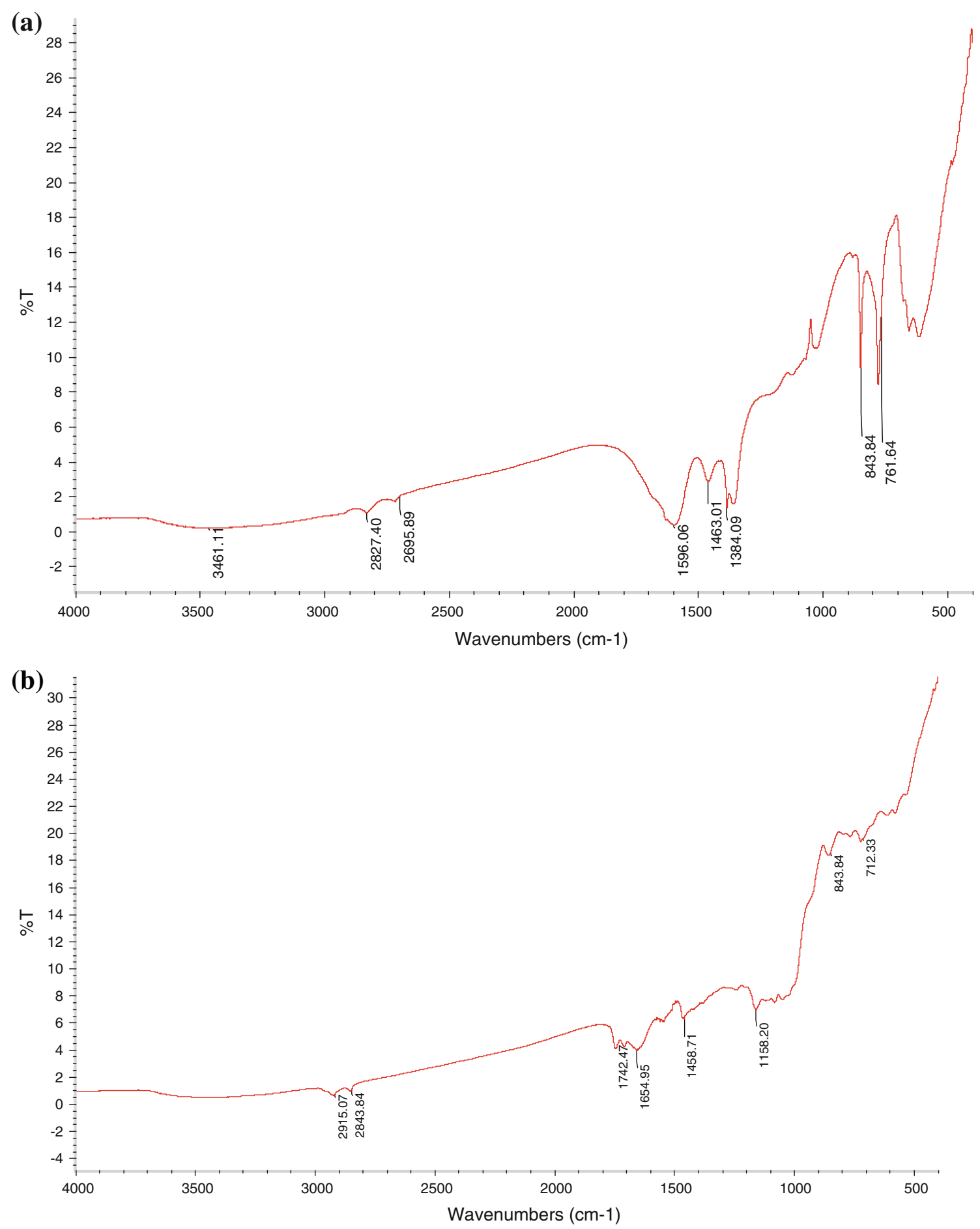

Fig. 2 FTIR spectra of mango leaf powder (a), and before biosorption (b) after biosorption $\left(4,000-500 \mathrm{~cm}^{-1}\right)$

lower number of $\mathrm{H}^{+}$and greater number of ligands with negatives charges results in greater metal ions biosorption (Feng et al. 2011). The percentage of As(III) ion uptake steeply increased to $67.5 \%$ in case of $\mathrm{RH}$ whereas, $74.3 \%$ in case of MLP and no further positive effect on As(III) removal was observed, probably due to limitations in metal ion mobility at higher $\mathrm{pH}$ values (Borah et al. 2009). The maximum removal of As(III) was obtained at $\mathrm{pH} 6$ for RH and $\mathrm{pH} 7$ for MLP. Similar value was found by Katsoyiannis and Zouboulis. (2002) and Sharma and Sohn (2009) that better removal of As(III) was achieved at $\mathrm{pH} 7$. 

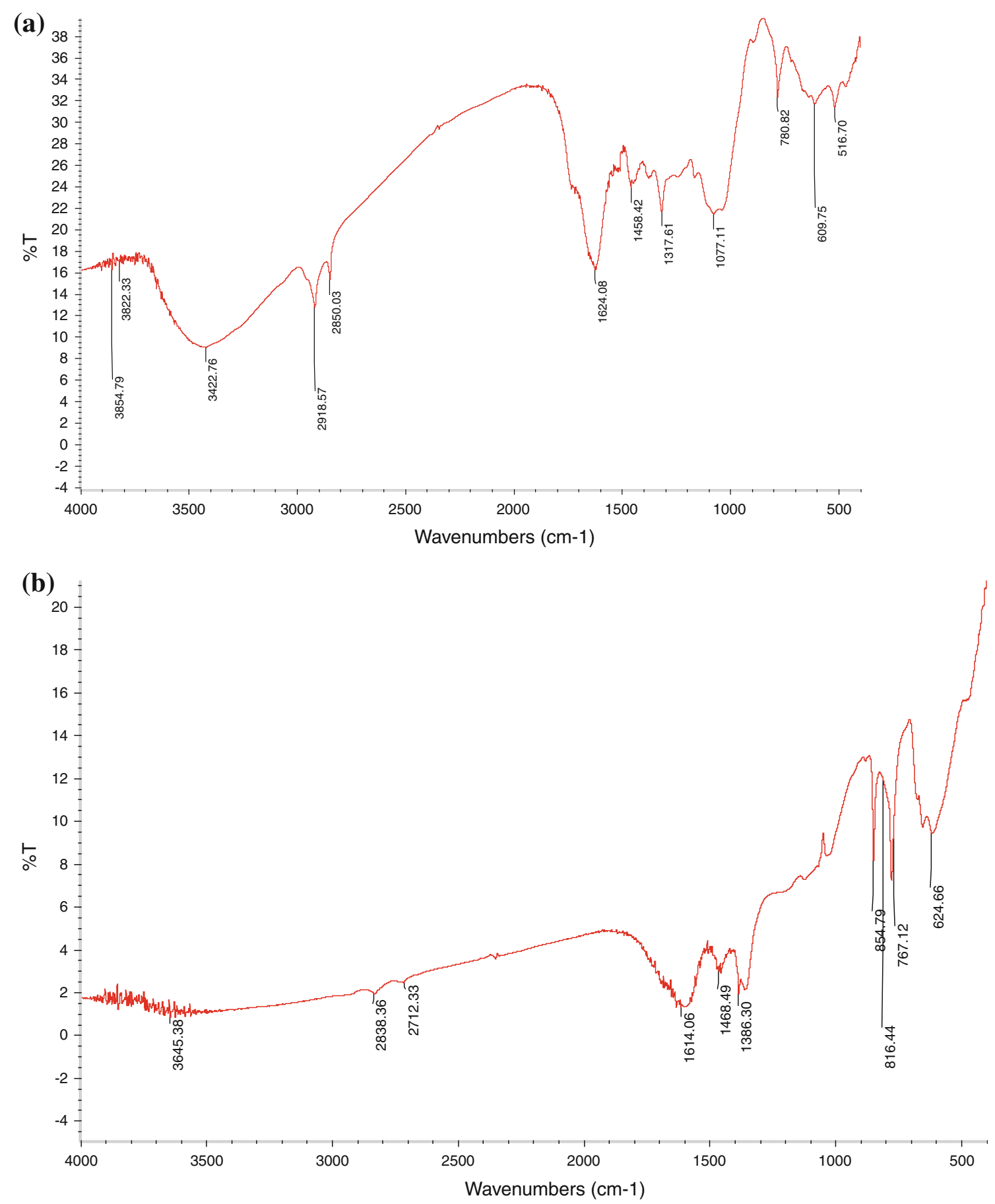

Fig. 3 FTIR spectra of mango leaf powder (a), and before biosorption (b) after biosorption $\left(4,000-500 \mathrm{~cm}^{-1}\right)$

\section{Effect of dosage}

The efficiency of sorbent to capture metal ions from contaminated water is a manifestation of how quickly it happens. Figure 5 shows that effect of biomass concentration for removal of As(III) onto MLP and RH surface varied from 2 to $50 \mathrm{~g} / \mathrm{l}$. It is clear that the amount of As(III) sorbed varied with the biosorbent concentration and that the amount sorbed increased with an increase in biosorbent dosage. The sorption capacity was observed to enhance from 40.8 to $98.5 \%$ as the sorbent mass was increased from 2 to $7 \mathrm{~g} / \mathrm{l}$ for As(III)-MLP system and from 49.6 to $94.8 \%$, the sorbent mass was increased from 2 to $6 \mathrm{~g} / \mathrm{l}$ As(III)-RH system (Fig. 5). The percentage As(III) removal increased with MLP and RH dosage was increased due to the increase in surface area and availability of more 


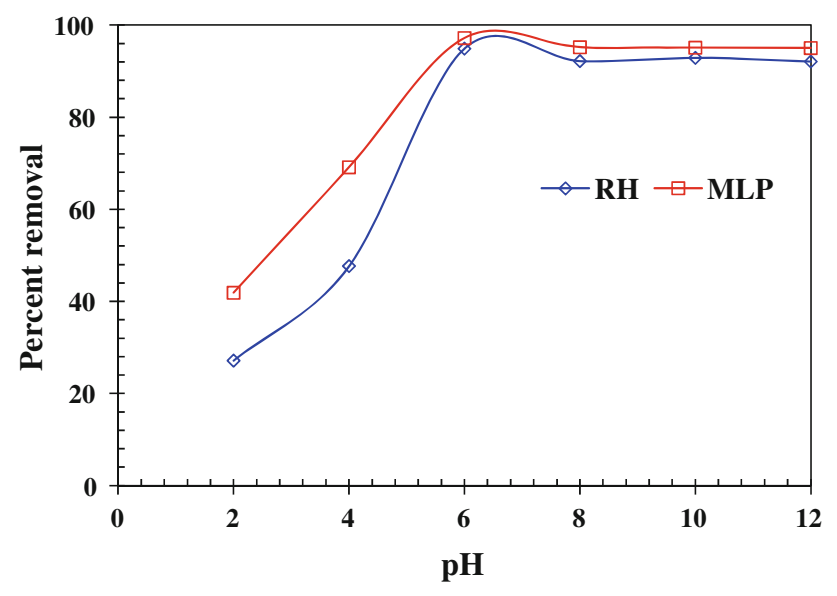

Fig. 4 Effect of $\mathrm{pH}_{0}$ on the biosorption of As(III) by MLP and $\mathrm{RH}$. $T=303 \mathrm{~K}, t=32 \mathrm{~h}, C_{0}=1,000 \mathrm{mg} / \mathrm{l}$

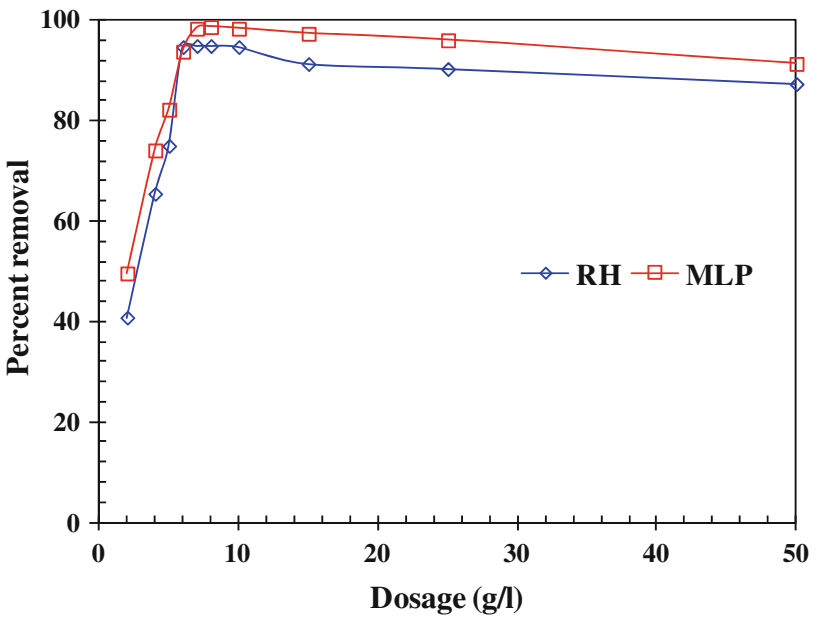

Fig. 5 Effect of adsorbent dose on the biosorption of As(III) by MLP and RH. $T=303 \mathrm{~K}, t=32 \mathrm{~h}, C_{0}=1,000 \mathrm{mg} / \mathrm{l}$

active sites (Chen et al. 2008; Bozic et al. 2009). Similar behaviour for the effect of sorbent concentrations on metal sorption capacity was observed and discussed in the literature for a variety of sorbents (Kumar et al. 2006; Oliveira et al. 2008; Saeed et al. 2009). The optimum percentage removal was achieved for As(III) at 7 and $6 \mathrm{~g} / \mathrm{l}$ for MLP and $\mathrm{RH}$, respectively. After that, the effect of increasing biosorbent concentration on the amount of As(III) sorbed was not significant, presenting only a slight increase in amount sorbed with an increase in biosorbent concentration.

\section{Biosorption kinetics}

Figure $6 \mathrm{a}, \mathrm{b}$ shows the kinetics of the biosorption of As(III) onto MLP and RH biomass for 32-h equilibrium time. The kinetic curve for As(III) ions showed that the amount of biosorption sharply increases with increasing contact time in the initial stage (0-30 min), and then gradually increases to reach an equilibrium value in approximately 120 and $150 \mathrm{~min}$ for MLP and RH systems, respectively. Maximum removal of metals was achieved within $60 \mathrm{~min}$ of contact time, suggests an excellent affinity of the biosorbent for the uptake of metals from aqueous solution (Pavan et al. 2006) due to the availability of a large number of sorption sites at the onset of the process and sticking probability was also high on the bare surface accounting high sorption rate. Further, the material was exclusively mesoporous and therefore, the diffusion of solute into the pores appears to be easier. Faster solute removal as well as low equilibration time attributes highly favourable sorptive interactions (Borah et al. 2009). A further increase in contact time had a negligible effect on the amount of biosorption. According to these results, the shaking time was fixed at 3 and $5 \mathrm{~h}$ for As(III)-MLP and As(III)-RH systems for the rest of the batch experiments to make sure that the equilibrium was reached.

A good correlation of the kinetic data explains the biosorption mechanism of the metal ion on the solid phase and also the residence time of sorption reaction (Chaturvedi et al. 2006). In order to evaluate the kinetic mechanism that controls the biosorption process, the pseudo-first-order and pseudo-second-order models were applied for the biosorption of As(III) ions on the MLP and RH. Biosorption kinetic data of As(III) ions are analysed using the Lagergren pseudo-first-order rate and pseudo-second-order equations (Lagergren 1898; Ho and McKay 1999):

$q_{\mathrm{t}}=q_{\mathrm{e}}\left[1-\exp \left(-k_{\mathrm{f}} t\right)\right]$

where, $q_{\mathrm{e}}$ is amount of the adsorbate adsorbed on the adsorbent under equilibrium condition and $k_{\mathrm{f}}$ is the pseudofirst-order rate constant.

It is required that calculated equilibrium adsorption capacity values, $q_{\mathrm{e}}$ (cal.), should be in accordance with the experimental $q_{\mathrm{e}}$ (exp.) values. Although the correlation coefficient values $\left(R^{2}\right)$ (not shown in table) are very high, the experimental $q_{\mathrm{e}}$ values do not agree with the calculated ones, obtained from the linear plots (Table 1). This suggests that the biosorption of As(III) ions does not follow pseudo-first-order kinetics. The biosorption kinetic data can be described by pseudo-second-order equation (Ho and Mckay, 1999):

$q_{\mathrm{t}}=\frac{t k_{\mathrm{S}} q_{\mathrm{e}}^{2}}{1+t k_{\mathrm{S}} q_{\mathrm{e}}}$

The initial adsorption rate, $h(\mathrm{mg} / \mathrm{g} \min )$ at $t \rightarrow 0$ is defined as

$h=k_{\mathrm{S}} q_{\mathrm{e}}^{2}$

The equilibrium adsorption capacity $\left(q_{\mathrm{e}}\right)$ and the initial sorption rate $(h)$ along with the rate constant $K_{\mathrm{s}}$ were 
Fig. 6 Effect of contact time and initial concentration for biosorption of As(III) by MLP and RH. Experimental data points given by the symbols and the lines predicted by the pseudo-second-order model. $m=7$ and $8 \mathrm{~g} / \mathrm{l}$ for MLP, RH, $T=303 \mathrm{~K}, \mathrm{pH}=7$ and 6 for MLP, RH
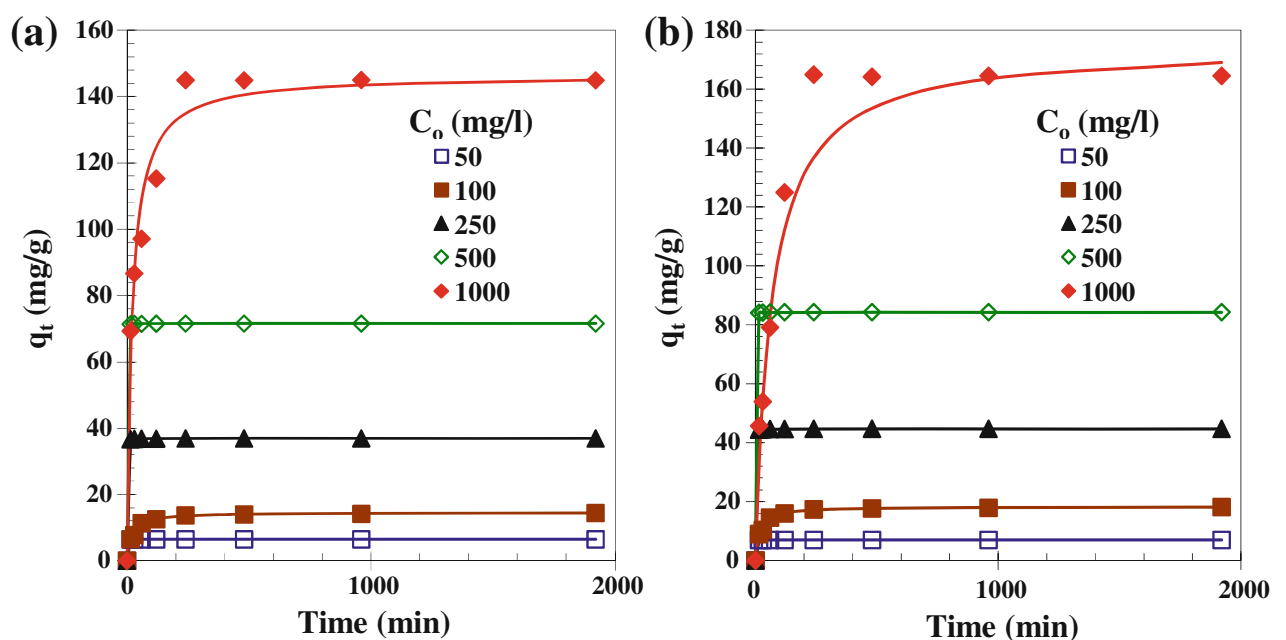

Table 1 Kinetic parameters for the removal of As(III) by MLP and RH ( $t=32 \mathrm{~h}, C_{0}=50-1,000 \mathrm{mg} / \mathrm{l}, T=303 \mathrm{~K}$ )

\begin{tabular}{|c|c|c|c|c|c|}
\hline$C_{0}(\mathrm{mg} / \mathrm{l})$ & $q_{\mathrm{e}, \text { calc }}(\mathrm{mg} / \mathrm{g})$ & $k_{\mathrm{S}}(\mathrm{g} / \mathrm{mg} \min )$ & $h(\mathrm{mg} / \mathrm{g} \min )$ & $R^{2}$ & MPSD \\
\hline \multicolumn{6}{|l|}{ As(III)-MLP system } \\
\hline 50 & 6.46 & 2.7213 & 113.82 & 0.999 & 0.0162 \\
\hline 100 & 14.53 & 0.0037 & 0.7908 & 0.996 & 7.8422 \\
\hline 250 & 36.88 & 0.3061 & 416.39 & 0.999 & 0.0445 \\
\hline 500 & 71.54 & 0.3121 & 597.45 & 0.999 & 0.0389 \\
\hline 1,025 & 146.60 & 0.0003 & 7.0605 & 0.989 & 16.2086 \\
\hline \multicolumn{6}{|c|}{ Internal diffusion: Weber-Morris method } \\
\hline$K_{\mathrm{id} 1}\left(\mathrm{mg} / \mathrm{g} \mathrm{min}{ }^{1 / 2}\right)$ & 0.0028 & 0.6246 & 0.0095 & 0.0117 & 6.219 \\
\hline$I_{1}$ & 6.435 & 4.732 & 36.729 & 71.369 & 48.478 \\
\hline$R^{2}$ & 0.8261 & 0.8741 & 0.7938 & 0.9641 & 0.9911 \\
\hline$K_{\mathrm{id} 2}\left(\mathrm{mg} / \mathrm{g} \min ^{1 / 2}\right)$ & 0.00002 & 0.0183 & 0.0005 & 0.0002 & 0.0075 \\
\hline$I_{2}$ & 6.466 & 13.59 & 24.912 & 71.54 & 145.22 \\
\hline$R^{2}$ & 0.850 & 1.000 & 0.892 & 1.000 & 1.000 \\
\hline \multicolumn{6}{|l|}{ As(III)-RH system } \\
\hline 50 & 6.96 & 2.72 & 132.20 & 0.999 & 0.015 \\
\hline 100 & 18.23 & 0.0035 & 1.17 & 0.996 & 7.25 \\
\hline 250 & 44.69 & 0.2621 & 523.73 & 0.999 & 0.043 \\
\hline 500 & 84.30 & 0.2668 & 896.06 & 0.999 & 0.038 \\
\hline 1,050 & 174.93 & 0.0001 & 2.59 & 0.986 & 27.14 \\
\hline \multicolumn{6}{|c|}{ Internal diffusion: Weber-Morris method } \\
\hline$K_{\text {id } 1}\left(\mathrm{mg} / \mathrm{g} \min ^{1 / 2}\right)$ & 0.0028 & 0.7287 & 0.0111 & 0.0137 & 18.819 \\
\hline$I_{1}$ & 6.935 & 7.0878 & 44.517 & 84.097 & 0.5046 \\
\hline$R^{2}$ & 0.826 & 0.874 & 0.794 & 0.964 & 0.989 \\
\hline$K_{\mathrm{id} 2}\left(\mathrm{mg} / \mathrm{g} \min ^{1 / 2}\right)$ & 0.00005 & 0.0214 & 0.0012 & 0.0002 & 0.0004 \\
\hline$I_{2}$ & 6.9663 & 17.193 & 22.212 & 84.296 & 8.972 \\
\hline$R^{2}$ & 0.850 & 1.000 & 0.998 & 1.000 & 0.982 \\
\hline
\end{tabular}

Pseudo-second-order model fitted data

determined from the non-linear fitting of the pseudo-second-order rate equation with the experimental data. It was found that the calculated $q_{\mathrm{e}}$ values agree well with experimental $q_{\mathrm{e}}$ values (Table 1). The fitting seems to be adequate and satisfactory (Oliveira et al. 2008). The experimental data presented in Fig. 6a, b for As(III)-MLP and As(III)-RH systems could be fitted well for the pseudosecond-order $\left(R^{2}=0.986-0.999\right)$ model of adsorption rate. 
However, the best adjustment was observed for the pseudosecond-order kinetic which is based on the assumption that rate limiting step is chemisorption involving valance forces through sharing or exchange of electrons between As(III) ion and the adsorbent provides the best correlation data for the As(III) ion (Urik et al. 2009). Similar phenomenon has been observed in the biosorption of heavy metals onto untreated coffee husks (Oliveira et al. 2008). It was found from experimental results that $98.8 \%$ removal for MLP and $93.6 \%$ removal for RH was achieved at $m=7$ and $6 \mathrm{~g} / \mathrm{l}$, respectively (Fig. 6a, b).

\section{Adsorption diffusion study}

The controlling mechanism of sorption was studied over a As(III) concentration range of from 50 to $1,000 \mathrm{mg} / \mathrm{l}$ in a $150 \mathrm{rpm}$ agitated batch system (McKay et al. 1981). Under well-mixed conditions, the external mass transport resistance is neglected and it is expected that the rate of uptake would be governed by the intraparticle or surface diffusion transport. A plot of $q_{\mathrm{t}}$ versus $t^{0.5}$ as proposed by Weber and Morris (1963) (Fig. 7a, b) shows fitting of the data by two linear portion for As(III)-MLP and As(III)-RH systems. This shows that two or more steps influence the sorption process. The model was used as

$q_{\mathrm{t}}=k_{\mathrm{id}} t^{1 / 2}+I$

where, $k_{\mathrm{id}}$ is the intra-particle diffusion rate constant, and the magnitude of $I$ gives an idea about the thickness of the boundary layer.

The curvature from the origin to the start of the first straight portion (not shown in figure) represents the boundary layer diffusion and/or external mass transfer effects (Crank 1965). It has been reported that the adsorption capacity decrease when the thickness of boundary layer decreases (Aksu 2001). The deviation of straight lines from the origin indicates that the pore diffusion is not the sole rate-controlling step. Therefore, the adsorption proceeds via a complex mechanism consisting of both surface adsorption and intra-particle transport within the pores of MLP and RH surface. The slope of the linear plots defines the rate of adsorption in the region where intra-particle diffusion is rate controlling and the rate constants can be calculated from these slopes. It seems that the intra-particle diffusion of As(III) into meso-pores (second linear portion) is the rate-controlling step in the adsorption process. The portion of the plots are nearly

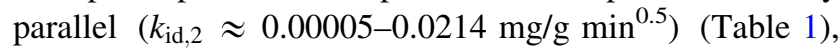
suggesting that the rate of adsorption of As(III) into the MLP and RH surface is comparable at all $C_{0}$. Slopes of first portions $\left(k_{\mathrm{id}, 1}\right)$ are higher for higher $C_{0}$. This corresponds to an enhanced diffusion of As(III) through macro-pores, and is attributed to the greater driving force for mass transfer at higher $C_{0}$.

\section{Biosorption isotherms}

Figure 8a, b presents the experimental biosorption isotherm of $\mathrm{As}(\mathrm{III})$ ion onto MLP and $\mathrm{RH}$ at range of temperature 283-318 K. Biosorption isotherms describe how adsorbate interacts with biosorbents and equilibrium isotherms are measured to determine the capacity of the biosorbent for metal ions. All the models equation is given in the isotherm modelling (Table 2). It could be seen that $q_{\mathrm{e}}$ increased initially with an increase in $C_{\mathrm{e}}$ until equilibrium was reached, after which $q_{\mathrm{e}}$ remained constant with further increase in $C_{\mathrm{e}}$. The most common types of models describing this type of system are the Langmuir and Freundlich isotherms. Both Langmuir and Freundlich models were evaluated for description of As(III) sorption isotherms (Table 2$)$. The equilibrium sorption capacity $\left(q_{\mathrm{e}}\right)$ is found to increase with an increase in temperature: 171.1 and
Fig. 7 Weber and Morris intraparticle diffusion plot for the biosorption of arsenic(III) by MLP and RH. $T=303 \mathrm{~K}$, $m=7$ and $8 \mathrm{~g} / \mathrm{l}$ for MLP, RH, $T=303 \mathrm{~K}, \mathrm{pH}=7$ and 6 for MLP, RH
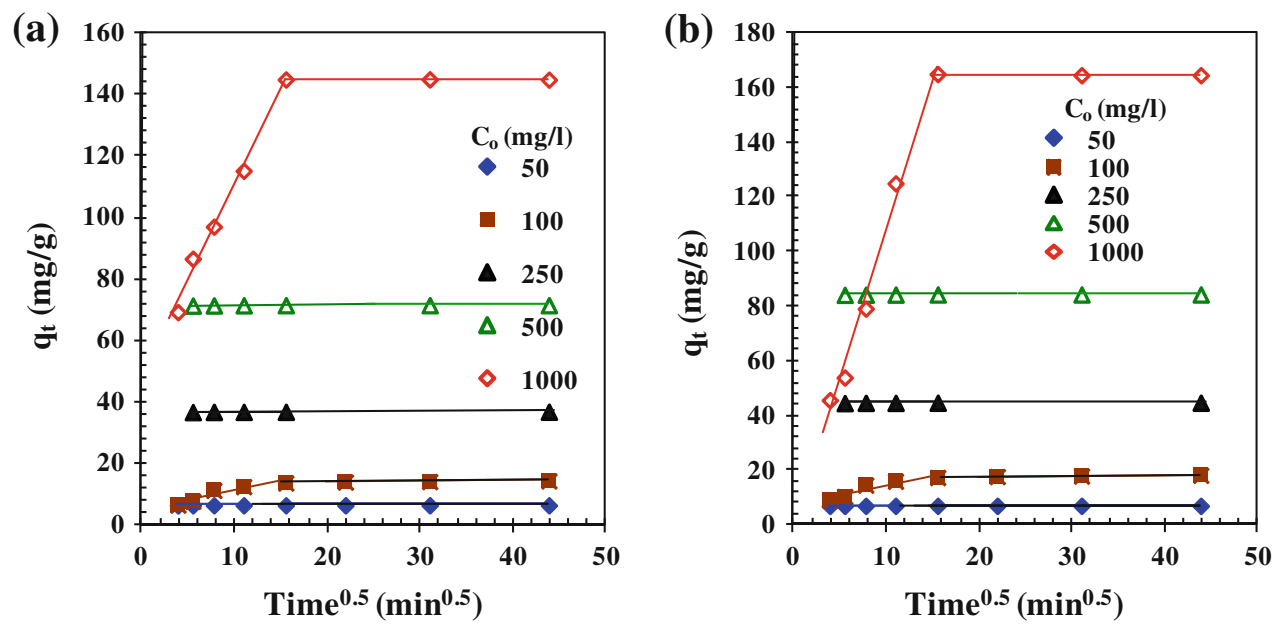
$199.12 \mathrm{mg} / \mathrm{g}$ at $283 \mathrm{~K}$ to 184.2 and $224.21 \mathrm{mg} / \mathrm{g}$ at $293 \mathrm{~K}$; to $214.4 \mathrm{mg} / \mathrm{g}$ and $224.21 \mathrm{mg} / \mathrm{g}$ at $303 \mathrm{~K}$; to $220.1 \mathrm{mg} / \mathrm{g}$ and $250.07 \mathrm{mg} / \mathrm{g}$ at $318 \mathrm{~K}$. This indicates the favourable effect of temperature on As(III) sorption onto the MLP and RH. This means that the adsorption of As(III) onto MLP and $\mathrm{RH}$ is an endothermic process. The Langmuir, Freundlich, Temkin and Redlich-Peterson isotherm parameters along with the coefficient of determination $\left(R^{2}\right)$ and HYBRID values for the fit of the adsorption of As(III) onto MLP and RH at various temperatures are given in Table 2. The $1 / n$ and $K_{\mathrm{F}}$ values of the Freundlich model are the measures of the surface heterogeneity and adsorption capacity of the adsorbate, respectively. If $1 / n<1$, then the adsorption process is favourable. The values of $1 / n$ obtained are less than one indicating favourable adsorption. Several researchers have reported Freundlich and Langmuir constants for adsorption of metal ions onto various biosorbents. Arsenic(III) sorption from aqueous solutions by MLP and RH was better described by Freundlich model (see solid lines in Fig. 8a, b) in comparison to all other models presented in the Table 2 . As it can be seen, the Freundlich isotherm gave better fits than the Langmuir isotherm, which illustrated that the biosorption on the surface of MLP and RH was a multilayer biosorption. Urik et al. (2009) and Mondal et al. (2006) reported the mechanism of As(III) adsorption onto modified sawdust and granular activated carbon seem to be formation of inner and outer sphere surface complex. Thus, the formation of chemical bond present in the surface of biomass and metal ions. The $R^{2}$ values (given in Table 2) alone are insufficient in determining the best isotherm model to represent the experimental data because they are mostly greater than 0.98 for all five models. The HYBRID values are smaller for Freundlich model as compared to that for other models.
So, it can be concluded that Freundlich model is the best among the four models for representing the adsorption isotherm data of the As(III) ion-MLP and As(III) ion-RH systems.

\section{Biosorption thermodynamics}

The Van't Hoff's plot for As(III), from which $\Delta H_{0}$ and $\Delta S_{0}$ values have been estimated (Table 3 and Fig. 9). The positive value of $\Delta S_{0}$ (144.38 and $247.17 \mathrm{~J} / \mathrm{mol} \mathrm{K}$ for As(III)-MLP and As(III)-RH systems) suggests increased randomness at the solid/solution interface with some structural changes in the adsorbates and the MLP, RH surface and an affinity of the MLP, RH towards As(III). The positive $\Delta S_{0}$ value also corresponds to an increase in the degree of freedom of the adsorbed species (Suresh et al. 2010). The positive values of $\Delta H_{0}(23.89$ and $52.26 \mathrm{~kJ} / \mathrm{mol}$ for As(III)-MLP and As(III)-RH systems) indicate endothermic nature of the adsorption process as was seen earlier with the effect of temperature. In chemisorption, the $\Delta H_{0}$ is, in the range of $30-70 \mathrm{~kJ} / \mathrm{mol}$ (Suresh et al. 2010). As seen earlier, the positive and large values of $\Delta H_{0}$ indicated that the sorption by chemisorption (Suresh et al. 2010). The negative free energy changes in As(III) ions-MLP and As(III) ions-MLP system were $-17.97,-18.03,-20.03$, -20.15 and $-17.42,-20.88,-22.31,-23.02 \mathrm{~kJ} / \mathrm{mol}$, respectively, indicating the biosorption process is spontaneous at range of temperature 283, 293, 303 and $318 \mathrm{~K}$, as observed (Suresh et al. 2010; Feng et al. 2011).

\section{Desorption study}

Figure 10 shows the desorption efficiencies of As(III) onto loaded MLP and RH by various desorbing agents. Solvent
Fig. 8 Equilibrium adsorption isotherms at different temperature for As(III)-MLP and $\mathrm{As}(\mathrm{III})-\mathrm{RH}$ system, $t=32 \mathrm{~h}, C_{0}=20-1,000 \mathrm{mg} / \mathrm{l}$, $m=7$ and $8 \mathrm{~g} / \mathrm{l}$ for MLP, RH, $T=303 \mathrm{~K}, \mathrm{pH}=7$ and 6 for MLP, RH. Experimental best data points are predicted by Freundlich equation
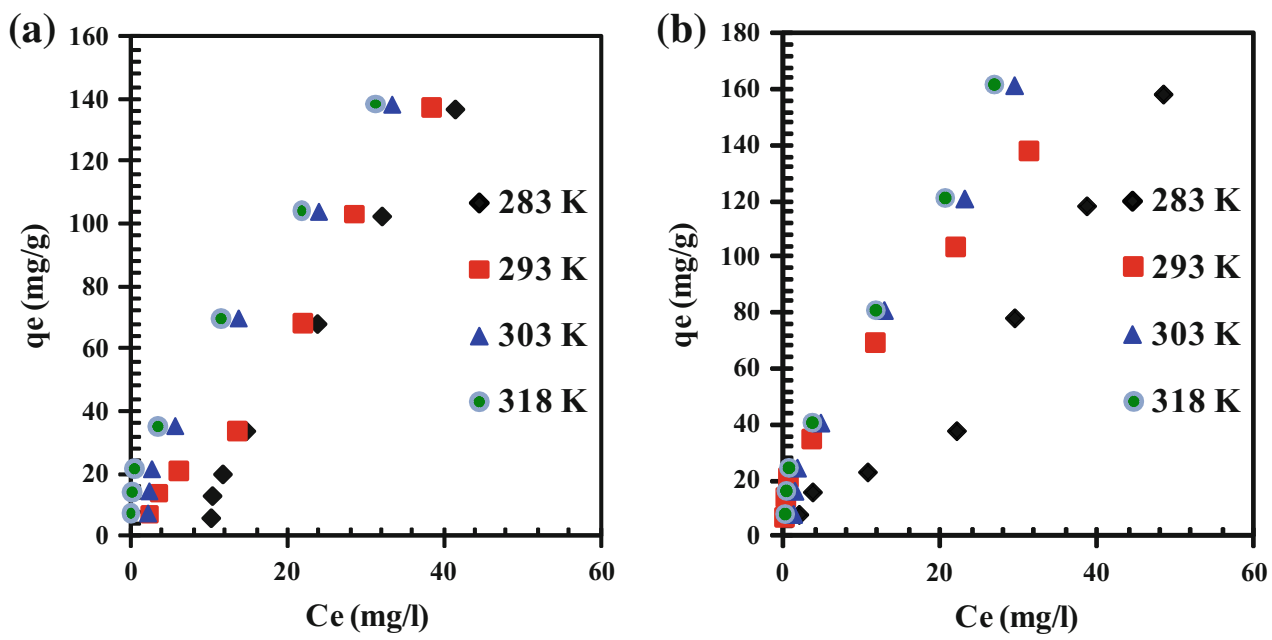
Table 2 Isotherm parameters for the removal of As(III) by MLP and RH $\left(t=32 \mathrm{~h}, C_{0}=20-1000 \mathrm{mg} / \mathrm{l}, T=303 \mathrm{~K}\right)$

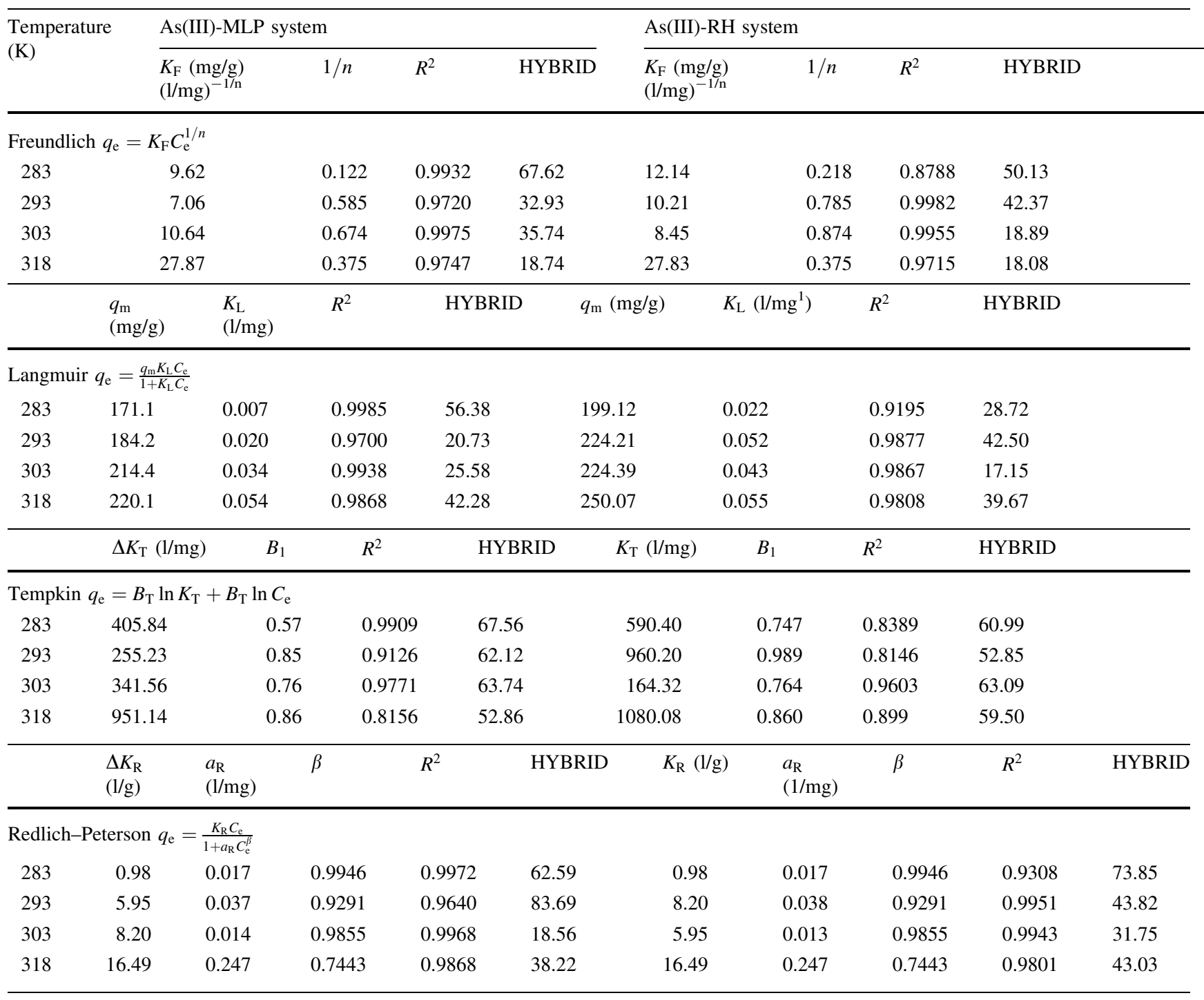

Arsenic adsorption onto MLP and RH at different temperatures

Table 3 Thermodynamics parameters for the biosorption of As(III) by MLP and RH $\left(t=32 \mathrm{~h}, C_{0}=20-1,000 \mathrm{mg} / \mathrm{l}\right)$

\begin{tabular}{lllll}
\hline $\begin{array}{l}\text { Temperature } \\
(\mathrm{K})\end{array}$ & $\begin{array}{l}K_{\mathrm{d}} \\
(\mathrm{l} / \mathrm{g})\end{array}$ & $\begin{array}{l}\Delta G_{0} \\
(\mathrm{~kJ} / \mathrm{mol})\end{array}$ & $\begin{array}{l}\Delta H_{0} \\
(\mathrm{~kJ} / \mathrm{mol})\end{array}$ & $\begin{array}{l}\Delta S_{0} \\
(\mathrm{~kJ} / \mathrm{mol} \mathrm{K})\end{array}$ \\
\hline $\begin{array}{llll}\text { MLP } \\
283\end{array}$ & 1.81 & -17.97 & 23.89 & 144.38 \\
293 & 1.63 & -18.03 & & \\
303 & 2.82 & -20.03 & & \\
318 & 2.03 & -20.15 & & \\
RH & & & & \\
283 & 1.63 & -17.42 & 52.26 & 247.17 \\
293 & 5.25 & -20.88 & & \\
303 & 6.99 & -22.31 & & \\
318 & 6.02 & -23.02 & & \\
\hline
\end{tabular}

desorption studies help in understanding the mechanism of the adsorption process and also check the stability of the loaded/spent adsorbent (Suresh et al. 2010; Sekhar et al. 2004). A literature indicated that dilute mineral, EDTA and caustic solution (Jenette et al. 1982; Sekhar et al. 2004) have been utilised to remove sorbed metal ions from the biomass/microorganisms. Therefore, reagents were evaluated for eluting sorbed As(III) from the MLP and RH. Nitric acid and EDTA was found to be a better eluant for the desorption followed by $\mathrm{HCl}$ and $\mathrm{NaOH}$ of $\mathrm{As}(\mathrm{III})$ with a maximum desorption efficiency of 69.5, 48.5\% and 79.4, $86.3 \%$ for As(III) loaded MLP and RH, respectively. The $\mathrm{Na}_{2} \mathrm{CO}_{3}$ eluted 63 and $59 \%$ of the As(III). Among all the eluents used, $\mathrm{HNO}_{3}$ and EDTA proved to be the best eluant. A major advantage of husks as low-cost sorbents is that 


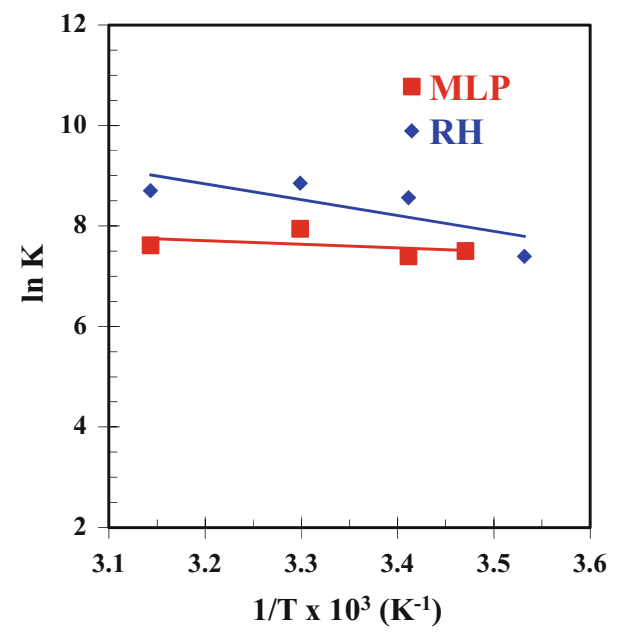

Fig. 9 Van't Hoff plot of adsorption equilibrium constant $\mathrm{K}$ for As(III) removal onto MLP and RH

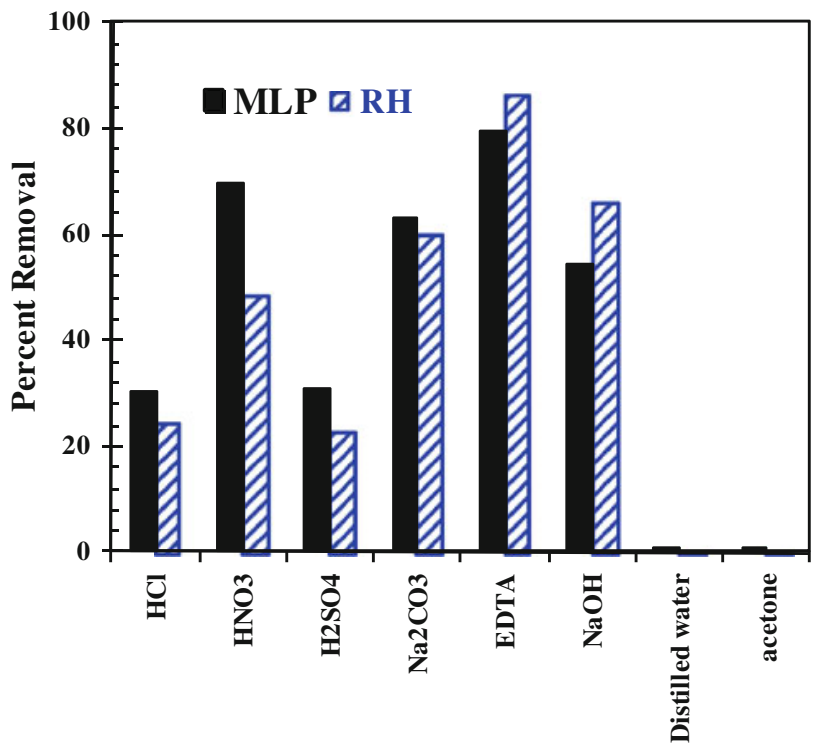

Solvent

Fig. 10 Desorption efficiencies of $\mathrm{As}(\mathrm{III})$ by various desorbing agents. $T=303 \mathrm{~K}, \quad t=32 \mathrm{~h}, C_{0}$ (desorbing agents) $=0.1 \mathrm{~N}$, $m=1 \mathrm{~g} / \mathrm{l}$

they are readily available in large quantities and do not present an alternative profitable use. Also, after metal sorption, the metal-laden husks can be used as a source of energy through combustion (Saenger et al. 2001; Oliveira et al. 2008).

\section{Conclusions}

The present investigation indicated that the potential of MLP and RH biomass as an economically feasible biosorbents for the removal of As(III) from aqueous solutions.
The sorption of $\mathrm{As}(\mathrm{III})$ was found to be highly $\mathrm{pH}$ dependent. The $q_{\mathrm{e}}$ is found to increase with an increase in temperature by As(III) sorption onto the MLP and RH. This means that the adsorption of As(III) onto MLP and $\mathrm{RH}$ is an endothermic process. Equilibrium sorption data was found to be well described by Freundlich isotherm. Hence sorption occurs on the heterogeneous surface of MLP and RD and uptake capacity of As(III) ions was rapid at the initial period of batch process. Moreover, it was found that sorption kinetics favour pseudo-second-order model compared to pseudo-first-order model. The regeneration of As(III) loaded MLP and RH was carried out using various solvents. $\mathrm{HNO}_{3}$ and EDTA was found to be a better eluant for the desorption followed by $\mathrm{HCl}$ and $\mathrm{NaOH}$ of $\mathrm{As}(\mathrm{III})$ with a maximum desorption efficiency of 69.5 , $48.5 \%$ and $79.4,86.3 \%$, respectively. Spent-MLP and RH can be used as source of energy through combustion processes.

\section{References}

Aksu Z (2001) Equilibrium and kinetic modeling of cadium(II) biosorption by $\mathrm{C}$. vulgaris in a batch system: effect of temperature. Sep Purif Tech 21(3):285-294

Amin N, Kaneco S, Kitagawa T, Begum A, Kastumata H, Suzuki T, Ohta K (2006) Removal of arsenic in aqueous solutions by adsorption onto waste rice husk. Ind Eng Chem Res 45:8105-8110

An HK, Park BY, Kim DS (2001) Crab shell for removal of heavy metals from aqueous solution. Water Res 15:1351-1356

Anawar HM, Akai J, Komaki K, Terao H, Yoshioka T, Ishizuka T, Safiullah S, Kato K (2003) Geochemical occurrence of arsenic in groundwater of Bangladesh: sources and mobilization processes. J Geochem Explor 77:109-131

Arslanoglu H, Soner Altundogan H, Tumen F (2008) Preparation of cation exchanger from lemon and sorption of divalent heavy metals. Bioresour Technol 99:2699-2705

Atkins P, Hassan M, Dunn C (2007) Poisons, pragmatic governance and deliberative democracy: the arsenic crisis in Bangladesh. Geoforum 38:155-170

Baraka H, Hall PJ, Heslop MJ (2007) Preparation and characterization of melamine-formaldehyde-DTPA chelating resin and its use as an adsorbent for heavy metals removal from wastewater. React Funct Polym 67:585-600

Barakat M, Sahiner N (2008) Cationic hydrogels for toxic arsenate removal from aqueous environment. $\mathrm{J}$ Environ Manage 88:955-961

Borah D, Satokawa S, Kato S, Kojima T (2009) Sorption of As $(\mathrm{V})$ from aqueous solution using acid modified carbon black. J Hazard Mater 162:1269-1277

Bozic D, Stankovic V, Gorgievski M, Bogdanovic G, Kovacevic R (2009) Adsorption of heavy metal ions by saw dust of deciduous trees. J Hazard Mater 171:684-692

Chatterjee A, Das D, Mandal BK, Chowdhury TR, Samanta G, Chakraborti D (1995) Arsenic in ground water in six districts of West Bengal, India: the biggest arsenic calamity in the world. Part I Arsenic species in drinking water and urine of the affected people. Analyst 120:643-650 
Chaturvedi PK, Seth CS, Misra V (2006) Sorption kinetics and leachability of heavy metal from the contaminated soil amended with immobilizing agent (humus soil and hydroxyapatite). Chemosphere 64:1109-1114

Chaudhuri SD, Kundu M, Banerjee M, Das JK, Majumdar P, Basu S, Roychoudhury S, Singh KK, Giri AK (2008) Arsenic-induced health effects and genetic damage in keratotic individuals: involvement of p53 arginine variant and chromosomal aberrations in arsenic susceptibility. Mutat Res 659:118-125

Chen WM, Wu CH, James EK, Chang JS (2007) Metal biosorption capacity of cupriavidus taiwaneusis and its effects on heavy metals by nodulated Minosa pudica. J Hazard Mater 151:364-371

Chen YN, Chai LY, Shu YD (2008) Study of arsenic(V) adsorption on bone char from aqueous solution. J Hazard Mater 160:168-172

Chio CP, Lin MC, Liao CM (2009) Low cost farmed shrimp shells could remove arsenic from solutions kinetically. J Hazard Mater 171:859-864

Choong S, Chuah YTG, Robiah Y, Gregory Koay F, Azni LI (2007) Arsenic toxicity, health hazards and removal technologies from water: an overview. Desalination 217:139-166

Costa ACA, Mesquita LMS, Tornovsky J (1996) Batch and continuous heavy metals by a brown seaweed from a zinc producing plant. Miner Eng 9:811-824

Crank J (1965) The mathematics of diffusion. Oxford Clarendon Press, London

Duker AA, Carranza EJM, Hale M (2005) Arsenic geochemistry and health. Environ Int 31(631):641

Feng N, Guo X, Liang S, Zhu Y, Liu J (2011) Biosorption of heavy metals from aqueous solutions by chemically modified orange peel. J Hazard Mater 185:49-54

Freundlich HMF (1906) Over the adsorption in solution. J Physical Chem 57:385-471

Ho YS, McKay G (1999) Pseudo-second order model for sorption processes. Process Biochem 34:451-465

Iqbal M, Saeed A, Zafar SI (2009) FTIR spectrophotometry, kinetics and adsorption isotherms modeling, ion exchange, and EDX analysis for understanding the mechanism of $\mathrm{Cd}^{2+}$ and $\mathrm{Pb}^{2+}$ removal by mango peel waste. J Hazard Mater 164:161-171

IS 1350 part I (1984) Methods of test for coal and coke, proximate analysis. Bureau of Indian standards, New Delhi

IS 355: 1984 (1985) Methods for the determination of chemical composition of ash of coal and coke. Bureau of Indian Standards, New Delhi

Jack CN, Wang J, Shraim A (2003) A global health problem caused by arsenic from natural sources. Chemosphere 52:1353-1359

Jenette JC, Smith JE, Hassett JM (1982) Factors influencing metal accumulation by algae. Natl Tech Inf Serv PB 83-149377, p 124

Kamsonlian S, Majumder CB, Chand S, Suresh S (2011) Biosorption of $\mathrm{Cd}(\mathrm{II})$ and $\mathrm{As}(\mathrm{III})$ ions from aqueous solution by tea waste biomass. African J Environ Sci Technol 5(1):1-7

Kara A, Uzun L, Sirli NB, Denizli A (2004) Poly(ethylene glycol dimethacrylate- $n$-vinyl imidazole) beads for heavy metal removal. J Hazard Mater 106:93-99

Katsoyiannis IA, Zouboulis AI (2002) Removal of arsenic from contaminated water sources by sorption onto iron oxide coated polymeric materials. Water Res 36:5141-5155

Khalid N, Ahmad S, Kiani SN, Ahmed J (1999) Removal of mercury from aqueous solutions by adsorption to rice husks. Sep Sci Technol 34:3139-3153

Khan S, Cao Q, Zheng YM, Huang YZ, Zhu YG (2008) Health risks of heavy metals in contaminated soils and food crops irrigated with wastewater in Beijing. China Environ Poll 152:686-692

Kumar YP, King P, Prasad VSRK (2006) Equilibrium and kinetic studies for the biosorption system of copper(II) ion from aqueous solution using Tectona grandis L.f. leaves powder. J Hazard Mater B137:1211-1217

Lagergren S (1898) About the theory of so-called adsorption of soluble substances. Kungliga Svenska Vetenskapsakademiens Handlingar 24(4):1-39

Langmuir I (1918) The adsorption of gases on plane surfaces of glass, mica and platinum. J Am Chem Soc 40:1361-1403

Lataye DH, Mishra IM, Mall ID (2009) Adsorption of $\alpha$-picoline onto rice husk ash and granular activated carbon from aqueous solution: equilibrium and thermodynamic study. Chem Eng J 147:139-149

Liu J, Ma Y, Xu T, Shao G (2010) Preparation of zwitterionic hybrid polymer and its application for the removal of heavy metal ions from water. J Hazard Mater 178:1021-1029

Maji SK, Pal A, Pal T (2008) Arsenic removal from real-life groundwater by adsorption on laterite soil. J Hazard Mater 151:811-820

Mandal BK, Chowdhury RT, Samanta G, Basu GK, Chowdhury PP, Chanda CR, Lodh D, Karan NK, Dhar RK (1996) Arsenic in groundwater in seven districts of West Bengal, India: the biggest arsenic calamity in the world. Curr Sci 70(976):986

McKay G, Allen SJ, McConvey IF, Otterburn MS (1981) Transport process in the sorption of coloured ions by peat particles. J Colloid Interface Sci 80:323-339

Mohan D, Pittman C (2007) Arsenic removal from water/wastewater using adsorbents-a critical review. J Hazard Mater 142:1-53

Mohapatra D, Mishra D, Park KH (2008) A laboratory scale study on Arsenic(V) removal from aqueous medium using calcined bauxite ore. J Environ Sci 20:683-689

Mondal P, Majumder CB, Mohanty B (2006) Laboratory based approaches for arsenic remediation from contaminated water: recent developments. J Hazard Mater 137:464-479

Oliveira WE, Franca AS, Oliveira LS, Rocha SD (2008) Untreated coffee husks as biosorbents for the removal of heavy metals from aqueous solutions. J Hazard Mater 152:1073-1081

Pandey PK, Yadav S, Nair S, Bhui A (2002) Arsenic contamination of the environment-a new perspective from central-east India. Environ Int 28:235-245

Pavan FA, Lima EC, Airoldi C, Gushikem Y (2006) Use of ponkan mandarin peels as biosorbent for toxic metal uptake from aqueous solutions. J Hazard Mater 137:527-533

Porter JF, McKay G, Choy KH (1999) The prediction of sorption from a binary mixture of acidic dyes using single- and mixed isotherm variants of the ideal adsorbed solute theory. Chem Eng Sci 54:5863-5885

Rahman MM, Sengupta MK, Ahamed S, Chowdhury UK, Hossain MA, Das B, Lodh D, Saha KC, Pati S, Kaies I, Barua AK, Chakraborti D (2005) The magnitude of arsenic contamination in groundwater and its health effects to the inhabitants of the Jalangi-one of the 85 arsenic affected blocks in West Bengal, India. Sci Total Environ 338:189-200

Redlich O, Peterson DL (1959) A useful adsorption isotherm. J Physical Chem 63:1024-1026

Saeed A, Iqbalb M, Holla WH (2009) Kinetics, equilibrium and mechanism of $\mathrm{Cd} 2+$ removal from aqueous solution by mungbean husk. J Hazard Mater 168:1467-1475

Saenger M, Hartge EU, Werther J, Ogada T, Siagi Z (2001) Combustion of coffee husks. Renew Energ 23:103-121

Sekhar CK, Kamala CT, Chary NS, Sastry ARK, Rao NT, Vairamani M (2004) Removal of lead from aqueous solutions using an immobilized biomaterial derived from a plant biomass. J Hazard Mater 108(1-2):111-117

Sha L, Yi GX, Chuan FN, Hua TQ (2010) Effective removal of heavy metals from aqueous solutions by orange peel xanthate. Trans Nonferrous Metals Soc China 20:187-191 
Sharma VK, Sohn M (2009) Aquatic arsenic: toxicity, speciation, transformations, and remediation. Environ Int 35:743-759

Singh N, Kumar D, Lal K, Raisuddin S, Sahu AP (2010) Adverse health effects due to arsenic exposure: modification by dietary supplementation of jaggery in mice. Toxicol Appl Pharmacol 242:247-255

Srivastava VC, Mall ID, Mishra IM (2007) Adsorption thermodynamics and isosteric heat of adsorption of toxic metal ions onto bagasse fly ash (BFA) and rice husk ash (RHA). Chem Eng J 132:267-278

Suresh S, Srivastava VC, Mishra IM (2010) Isotherm, thermodynamics, desorption and disposal study for the adsorption of catechol and resorcinol onto granular activated carbon. J Chem Eng Data 56(4):811-818

Suzuki M, Fujii T (1982) Concentration dependence of surface diffusion coefficient of propionic acid in activated carbon particles. Am Inst Chem Eng J 28:380-385

Tapio S, Grosche B (2006) Arsenic in the aetiology of cancer. Mutat Res/Rev Mutat Res 612:215-246

Temkin MI, Pyzhev V (1940) Kinetics of ammonia synthesis on promoted iron catalysts. Acta Phys chim Sin 12:327-356

Tseng CH, Huang YK, Huang YL, Chung CJ, Yang MH, Chen CJ, Hsueh YM (2005) Arsenic exposure, urinary arsenic speciation, and peripheral vascular disease in black foot disease-hyperendemic villages in Taiwan. Toxicol Appl Pharmacol 206:299-308

Urik M, Littera P, Seve J, Kolencik M, Cernansky S (2009) Removal of $\operatorname{arsenic}(\mathrm{V})$ from aqueous solution using chemically modified sawdust of sprunce (Picea abies): kinetics and isotherm studies. Int J Environ Sci Tech 6(3):451-456

Volesky B (1994) Advances in biosorption of metals: selection of biomass types. Microbiol Rev 14:291-302

Wan Ngah WS, Hanafiah MAKM (2007) Removal of heavy metal ions from wastewater by chemically modified plant wastes as adsorbents: a review. Bioresour Technol 99:3935-3948

Wang Y, Zhu K, Wang F, Yanagisawa K (2009) Novel Fe/glass composite adsorbent for As(V) removal. J Environ Sci 21:434439

Weber WJ, Morris JC (1963) Kinetics of adsorption on carbon from solution. J Sanitary Eng Div, ASCE 89:31-60

Wei G, Fan L, Zhu W, Fu Y, Yu J, Tang M (2009) Isolation and characterization of the heavy metal resistant bacteria CCNWRS33-2 isolated from root nodule of Lespedeza cuneata in gold mine tailings in China. J Hazard Mater 162(50):56

Yoshida T, Yamauchi H, Sun GF (2004) Chronic health effects in people exposed to arsenic via the drinking water: dose-response relationships in review. Toxicol Appl Pharmacol 198(243):252

Zavar MH, Hashemi A (2000) Evaluation of electrochemical hydride generation for spectrophotometric determination of As(III) by silver diethyldicarbamate. Talanta 52:1007-1014

Zhu H, Jia Y, Wu X, Wang H (2009) Removal of arsenic from water by supported nano zero-valent iron on activated carbon. J Hazard Mater 172:1591-1596 